\title{
Therapeutic Strategies for Novel Corona Virus Disease (COVID-19): A Comprehensive Review
}

\section{Manoj Gadewar*, Mohd Kafeel and Dharmender}

Department of Pharmacology, School of Medical and Allied Sciences, K.R.

Mangalam University, Gurugram, Haryana, India

*Corresponding Author: Manoj Gadewar, Professor, Department of

Pharmacology, School of Medical and Allied Sciences, K.R. Mangalam University,

Gurugram, Haryana, India.
Received: December 08, 2020

Published: January 11, 2021

(C) All rights are reserved by Manoj Gadewar., et al.

\section{Abstract}

A newly emerged Human Coronavirus (HCoV) was reported in month of Dec 19 in Wuhan city of China (COVID-19). Due to high virulence ability and resistance of corona virus, several studies were carried out to screen existing drugs like antiviral, anti-malarial and anti-tubercular as potential targets for the treatment of disease. Therefore, its essential to develop an effective treatment strategy to control the virus spread and prevent the disease. In this review Here, we have reported the novel approaches and strategies that were used to treat and prevent COVID infection. Although it seems that antiviral drugs, antiprotozoal, antibacterial drug, an antimalarial drug, and immunosuppressive drug are effective in improving clinical manifestation, there is no definite treatment protocol. Lymphocytopenia, excessive inflammation, and cytokine storm followed by acute respiratory distress syndrome are still unresolved issues that making the disease more severe. Various herbal drugs derived from Indian traditional medicines, Chinese herbals medicine/traditional Chinese medicine (CHM/TCM) were used to prevent the progression of disease.

Keywords: COVID-19; SARS-CoV-2; World Health Organization (WHO)

\section{Introduction}

The first case of newly emerged Human Corona virus (HCoV) was reported in month of Dec 2019 in Wuhan city of China (COVID-19) [1]. On $12^{\text {th }}$ January 2020 World Health Organization (WHO) declares COVID-19 is a pandemic and caused by severe acute respiratory syndrome coronavirus 2 (SARS-CoV-2). SARSCoV-2 is a non-segmented RNA virus and mainly identified in the broncho-alveolar secretions, sputum and saliva [2]. The virus belongs to the family Coronaviridae and genus Betacoronavirus which is interrelated to severe acute respiratory syndrome coronavirus (SARS-CoV) and (ME RS-CoV) [3,4].
The various symptoms of COVID-19 are chest congestion, fever, respiratory distress, myalgia, fatigue loss of appetite, shortness of breath, cough and headache, the $1^{\text {st }}$ case of COVID-19 in India was reported on 30 Jan 2020 in Kerala and as on December 2020 more the 95 Lakhs peoples were suffered from the diseases with more than 1 lakh of deaths $[5,6]$.

Critics of the specific Coronavirus CSS idea have guaranteed that "cytokine storm has basically no definition" [7] and that there is absolute "no proof that will Coronavirus will provoke cytokine storm" in the patient [8]. Cytokine storm is a clinical aggregate of immune dysregulation recognized by perpetuated service of lymphocytes 
and macrophages that leads to secretion of large quantities of cytokines which causes systemic swelling and multi-organ failure with high mortality.

\section{Interleukin-6 and COVID-Cytokines storm}

In early scientific studies another mediator in COVID-19 is elevated level of interleukins-6 (IL-6) [7,8]. In COVID-cytokines storm numerous inflammatory cytokines like IL-1, IL-10, and tumor necrosis factor(TNF)- $\alpha$ are raised approximately 2-100 times above normal levels, whereas IL-6 shows much higher concentration as compared to other interleukins. Some studies reported that marked elevation in serum IL-6 levels in the $100-10,000 \mathrm{pg} / \mathrm{mL}$ range in patients with serious disease [9-11]. These markedly elevated IL-6 levels in COVID-CSS are similar in magnitude to serious CAR T-cell CRS [19] and higher than other hyper-IL-6 syndromes such as metacentric cattleman disease, where IL- 6 is elevated but typically $<100 \mathrm{pg} / \mathrm{mL}$ [12]. HLH is said to encompass a varied spectrum of "hyper ferritinemia hyper-inflammatory syndromes with a common terminal pathway but with different pathogenetic roots" [13].

IL-6 is difficult disks immune dysregulation plus respiratory failing within COVID-CSS will be quickly accumulating. Raised serum IL-6 will be linked with lymphopenia, reduced lymphocyte cytotoxicity and endothelial service. These types of defense defects may become partially renewed simply by therapy with IL-6 blockade with tocilizumab $[14,15]$. Study related to IL-6 pointed out that concentration of IL-6 $>80 \mathrm{pg} / \mathrm{mL}$ and C-reactive proteins concentration $>97 \mathrm{mg} / \mathrm{L}$ is very predictive and is associated with respiratory system failure [9].

\section{Life cycle of COVID-19}

The life cycle of COVID-19 begins in host cells once it reaches to lungs and binds to the type-II pneumocytes of the alveoli using its spike proteins (S protein) to the cellular receptor Angiotensin converting enzyme-2 (ACE-2). After binding to the receptor conformational changes in the $S$ protein facilitates viral envelope fusion with the cell membrane through the endosomal pathway. Following fusion with host cells, virus injects its positive single stranded RNA (+SSRNA) into host cell which then translates into viral repli-

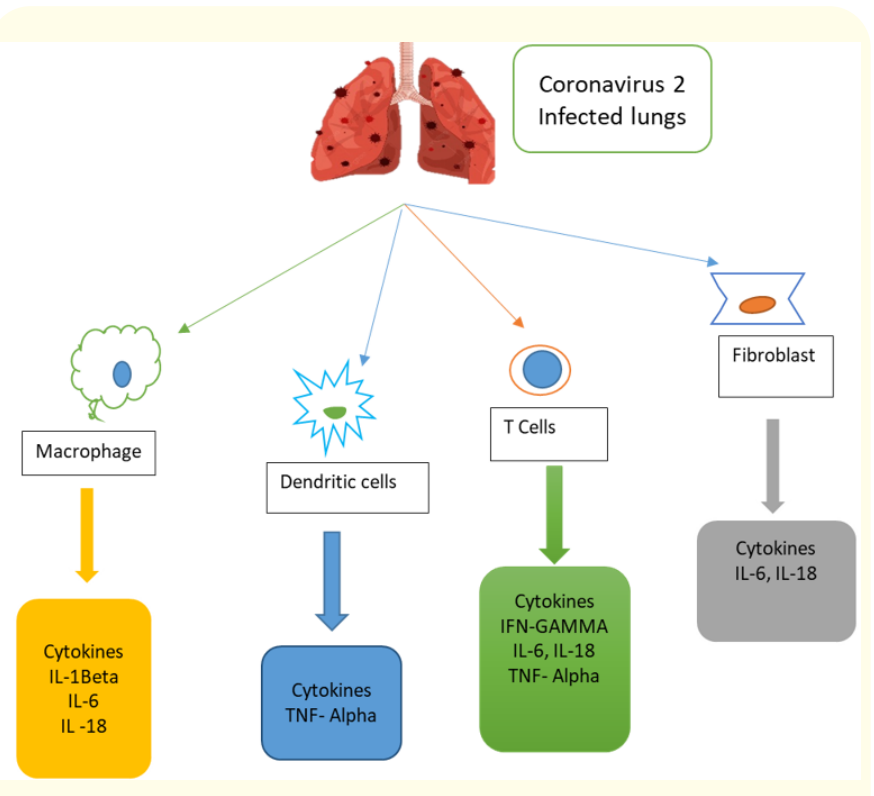

Figure 1: Inter-relation of various mediators in COVID-19.

case poly proteins pp1a and $1 \mathrm{ab}$ and results in to cleavage to small products by viral proteinases. The polymerase produces a series of sub-genomic mRNAs by discontinuous transcription and finally translated into relevant viral proteins. Host RNA dependent RNA polymerase converts the viral RNA into new virions genome. Viral proteins and genome RNA are subsequently assembled into virions in the endoplasmic reticulum and Golgi apparatus and then transported via vesicles and released out of the cell (Figure 2).

Healthy person gets infected when they come in contact with infected person. Once at the surface, the virus reaches to alveolar type-2-pneumocytes where it attaches with spike protein with ACE2 receptor of type- 2 cells. Following fusion with host cells, virus injects its positive single stranded RNA (+ssRNA) into host cell. Host cells, ribosome's translates the viral into large viral proteins which is further chopped into smaller proteins and used to make the structural proteins of progeny virions. Host RNA dependent RNA polymerase converts the viral RNA into new virions genome. Progeny virus after completing the life cycle burst the host cells, starts infection into nearby cells. In severely infected patients, virus also affects the vital organs like kidney and heart. 


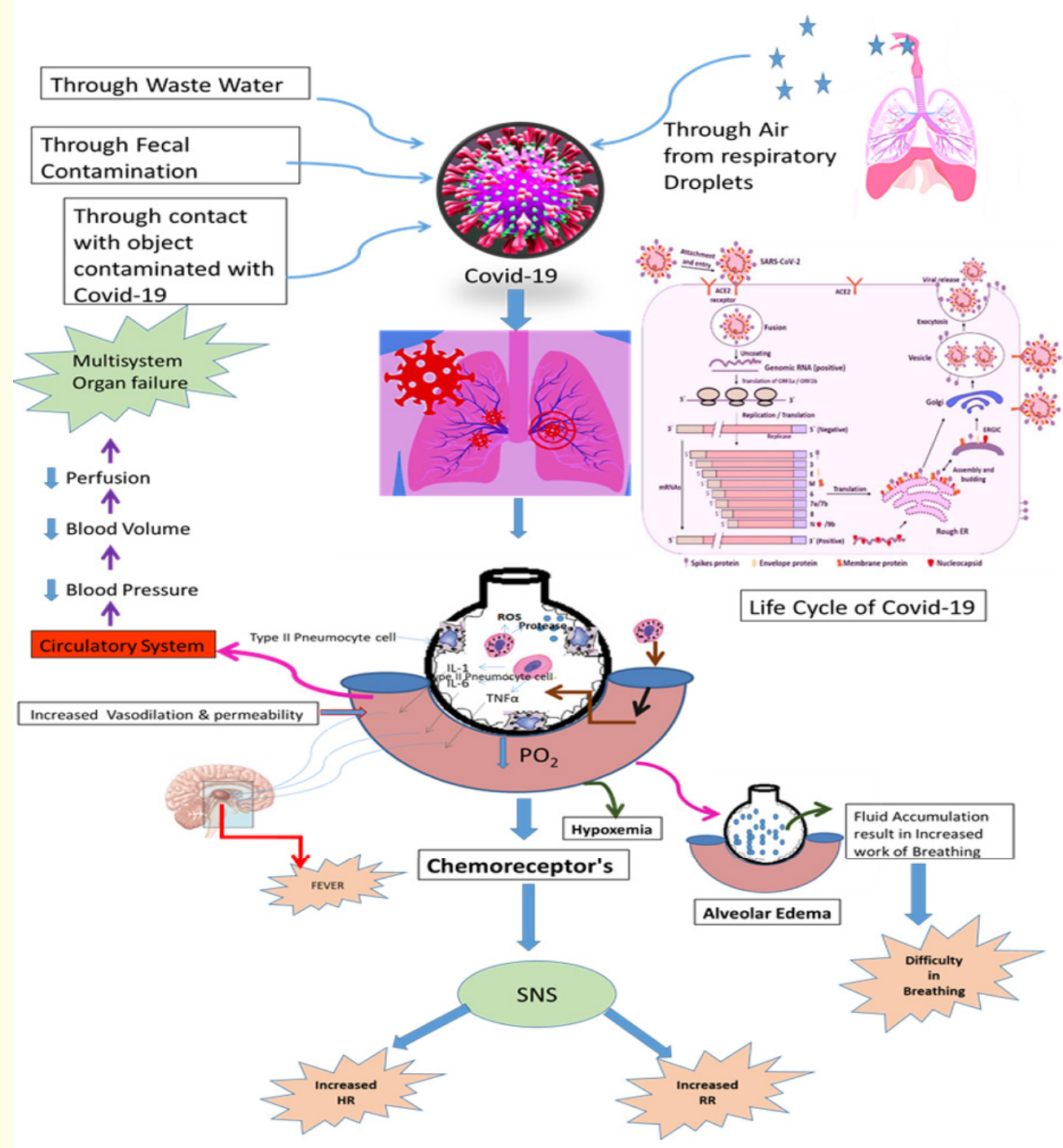

Figure 2: Life cycle of COVID-19.

To date there is no effective medicine available for the treatment of COVID-19 hence in this review we focused on repurposing of drugs used in traditional Chinese and Indian as well as allopathic system of medicine (Figure 3) which may be used alone or in combination to get maximum advantage of therapy.

\section{Treatment strategies for COVID-19}

\section{Antibacterial drug}

\section{Teicoplanin}

It is a semisynthetic glycopeptide antibiotic used to treat serious infections caused by gram-positive bacteria. This drug showed 


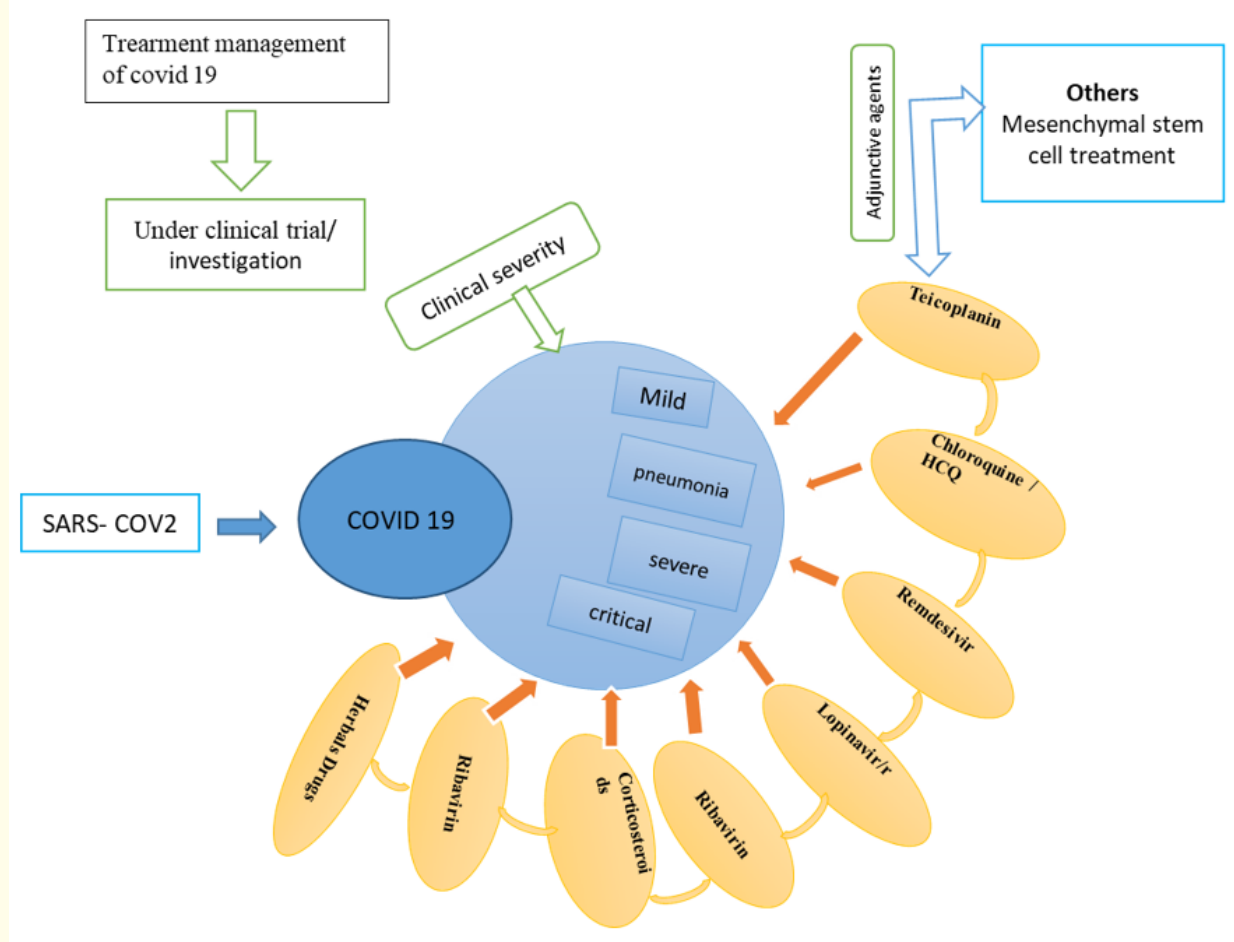

Figure 3: Drugs in treatment of COVID-19.

prominent effect when taken at a dose of $400 \mathrm{mg}$ once a day to treat infection associated with corona virus [16]. It acts by inhibiting spike viral protein by cathepsin $\mathrm{L}$ which is responsible for the release of genomic viral RNA [17].

\section{Antiprotozoal drug}

\section{Chloroquine/hydroxyl chloroquine}

Chloroquine acts by inhibiting the virus at the entry-level to the host cell while if it already inside the cell then it prevents the replication of the virus by changing the acidic $\mathrm{pH}$ of DNA replication and its organelles. Some researchers found that hydroxyl chloroquine is more safer as compared to chloroquine and showed better results in covid 19 by decreasing the cytokines storm and reducing the inflammatory response. it has an inhibitory effect by interfering with the glycosylation of the angiotensin-converting enzyme 2 [18,19]. It decreases the proinflammatory cytokines production against covid 19 [19].

\section{Antiviral drugs}

Remdesivir

Remdesivir was identified by the Gilead Sciences for the treatment of hepatitis $\mathrm{C}$, is a broad-spectrum antiviral drug it shows effective results against SARS COV pandemic disease in 2003 which is likely matched with SARS COV2. This drug is repurposed for the emergency use in the treatment of COVID after approval from US food and Drug Administration for 19 [20]. It showed prominent results in clinical study and found 31 percent effective as compared to other drugs. The recovery time of this drug is 11 days vs. 15 days in the placebo and reducing mortality $[17,21]$.

\section{Lopinavir/ritonavir}

Lopinavir is the most common antiviral drug used to treat various types of infectious diseases it is broad-spectrum antiviral drug. Recent studies showed its effectiveness against SARS COV2. It 
showed inhibitory activity against the main protease and prevents the entry of virus into host cell. ritonavir has greater binding efficiency. Recent study showed that lopinavir and remdesvir but not ritonavir prevented the SARS COV2 replication [22]. It is recommended that this drug decreases the viral load which is responsible for the discontinuation of antiviral properties. The recommended dose of lopinavir and ritonavir is 400 and $100 \mathrm{mg}$ for the duration of 6 to 15 days respectively [23,24].

\section{Ribavirin}

It is a guanosine analog and possess broad-spectrum antiviral activity, it prevents the inosine monophosphate dehydrogenase, thus removing the guanosine from the cell. It is also an inhibitor of RNA synthesis $[24,25]$. It was given intravenously $8 \mathrm{mg} / \mathrm{kg}$ every 8 hours for 14 days for achieving effective and better outcomes. Ribavirin gives better results when given in combination with lopinavir/ritonavir for the treatment of covid 19 [23,26,27].
Herbals drugs

Herbal drugs proven to be most effective for reducing the symptoms of COVID-19 [28]. They play a vital role in boosting immune response to fight against various types of diseases. Which is mainly due to specific immunomodulation is to be understood because of local and systemic interventions for treatment of various diseases [29]. Herbal medicines will serves as an alternative to allopathic medicines due to lower adverse effect and wide margin of safety. In China, the National Health Commission has announced that herbal medicines will be used together with western medicine to achieve better results for the treatment of COVID-19 [30]. Unani system of medicines employees use of plant and related product derived from it and effective against treatment of various diseases which are presented by Arabs and Persians in India [32]. The various unani preparation used for treatment of COVID-19 to boost immunity were depicted in table 1.

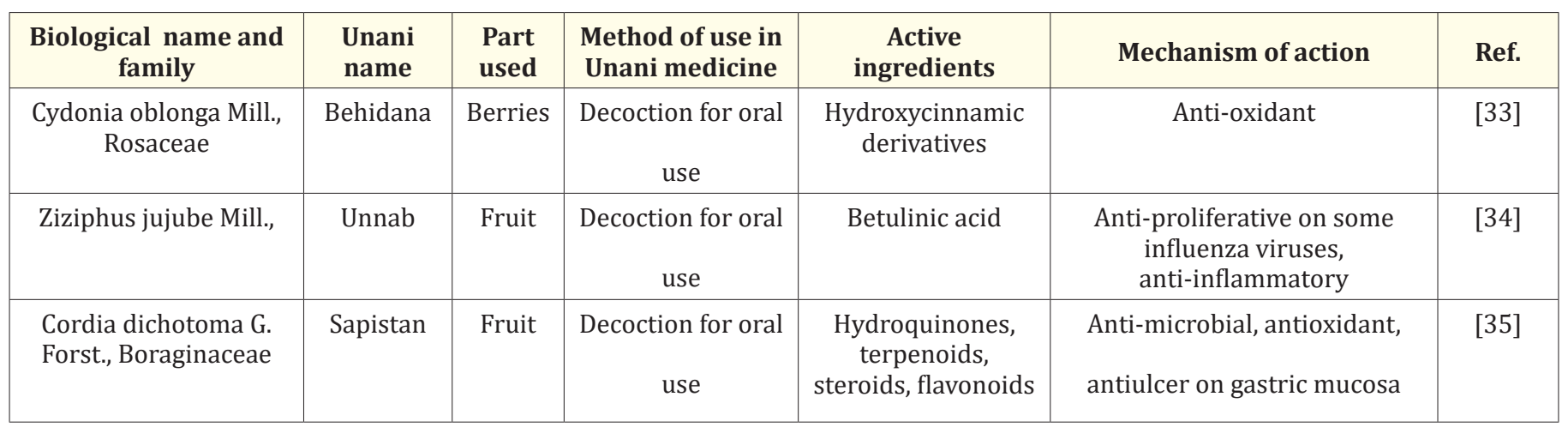

Table 1: Commonly used Unani medicines in treatment of COVID-19.

\section{Homeopathic medicines}

It was introduced as an alternative system of medicine by German scientist Samuel Hahnemann in (1755-1843) more than 200 years ago [36,37]. Homeopathic medicines are widely used to treat viral infections and bacterial infections. In India, AYUSH approved homeopathic medicines for the treatment of coronavirus on January 30, 2020. Arsenic album 30 showed prominent effects against
COVID 19. It is obtained from the metal arsenic which is given in empty stomach for a duration of 3 days which may be responsible for boosting the natural defense mechanism of body $[28,38]$.

Chinese herbals medicine/traditional chinese medicine (CHM/TCM)

CHM are widely used to treat SARS-CoV-2 in China. The Institute of Pharmacology of the Academy of Sciences has identified 30 
CHM drugs. China used its first medical treatment using CHM at Jinyintan Hospital on 26 January 2020 [31]. Some of the common medicinal plants used in TCM were depicted in table 2 and 3.

\begin{tabular}{|c|c|c|c|}
\hline Severity & $\begin{array}{c}\text { Pattern } \\
\text { Identification }\end{array}$ & $\begin{array}{c}\text { Composition of herbal } \\
\text { formula }\end{array}$ & Ref \\
\hline Mild & $\begin{array}{l}\text { Seasonal } \\
\text { epidemic } \\
\text { invading the } \\
\text { exterior-de- } \\
\text { fense }\end{array}$ & $\begin{array}{c}\text { Lonicerae Flos, Platycodonis } \\
\text { Radix, Forsythiae fructus, } \\
\text { Menthae Herba, Schizonepe- } \\
\text { tae spica, Lophatheri Herba, } \\
\text { Glycine Semen preparatum, } \\
\text { Phragmitis Rhizoma, Arctii } \\
\text { Semen } \\
\text { Cyperi Rhizoma, Citrireticu- } \\
\text { latae Pericarpium, Peril- } \\
\text { lae folium,Glycyrrhizae Radix } \\
\text { et Rhizoma, Bupleuri Radix, } \\
\text { Saposhnikoviae Radix, Cin- } \\
\text { namomi ramulus, Osterici seu } \\
\text { notopterygii Radix et Rhizoma }\end{array}$ & [39] \\
\hline Moderate & $\begin{array}{l}\text { Dampness- } \\
\text { heat blocking } \\
\text { the lung }\end{array}$ & $\begin{array}{c}\text { Ephedrae Herba, Glycyrrhizae } \\
\text { Radix et Rhizoma, Armeniacae } \\
\text { Semen amarum, Gypsum fibro- } \\
\text { sum, Amomi Fructus rotundus, } \\
\text { Coicis Semen, Magnoliae Cor- } \\
\text { tex, Pinelliae Rhizoma praepa- } \\
\text { ratum, Talcum, Helwingiae } \\
\text { Medulla, Stachyuri Medulla, } \\
\text { Lophatheri Herba } \\
\text { Citri Reticulatae Pericarpium, } \\
\text { Magnoliae Cortex, Atractylodis } \\
\text { Rhizoma, Glycyrrhizae Radix } \\
\text { et Rhizoma, Pinelliae Rhizoma, } \\
\text { Agastachis Herba, Amomi tsao- } \\
\text { ko Fructus }\end{array}$ & [39] \\
\hline Severe & $\begin{array}{l}\text { Heat toxin } \\
\text { blocking the } \\
\text { lung } \\
\text { Intense heat } \\
\text { toxin with } \\
\text { blockage of } \\
\text { bowel Qi and } \\
\text { dysphagia }\end{array}$ & $\begin{array}{l}\text { Gypsum fibrosum, Armeniacae } \\
\text { Semen amarum, Rhei Radix } \\
\text { et Rhizoma, Trichosanthis } \\
\text { fructus, Scutellariae Radix, } \\
\text { Talcum, Artemisiae scopariae } \\
\text { Herba, Fritillariae cirrhosae } \\
\text { Bulbus, Acori tatarinowii } \\
\text { Rhizoma,Akebiae caulis, } \\
\text { Forsythiae fructus, Agasta- } \\
\text { chis Herba,Amomi fructus } \\
\text { Rotundus, Belamcandae } \\
\text { Rhizoma,Menthae Herba. } \\
\\
\text { Rhei Radix et Rhizoma (Enema } \\
\text { using herbal decoction) }\end{array}$ & [39] \\
\hline
\end{tabular}

Table 2: Chinese herbal medicines for COVID-19.

\begin{tabular}{|c|c|c|}
\hline TCM Material & Mechanism of action & Ref \\
\hline $\begin{array}{l}\text { Plant-derived phenolic } \\
\text { compounds and root ex- } \\
\text { tract of Isatis Indigotica }\end{array}$ & $\begin{array}{l}\text { Inhibit the cleavage activity of } \\
\text { SARS-3CLpro enzyme }\end{array}$ & {$[40]$} \\
\hline \multirow[t]{3}{*}{$\begin{array}{l}\text { Water extract of } \\
\text { Houttuynia cordata }\end{array}$} & $\begin{array}{l}\text { Inhibit the viral SARS-3CLpro } \\
\text { activity }\end{array}$ & {$[41]$} \\
\hline & $\begin{array}{l}\text { Block viral RNA-dependent } \\
\text { RNA polymerase activity } \\
\text { (RdRp) }\end{array}$ & \\
\hline & Immunomodulation & \\
\hline Chinese Rhubarb extracts & Inhibit SARS-3CLpro activity & {$[42]$} \\
\hline $\begin{array}{l}\text { Quercetin and TSL-1 from } \\
\text { Toona sinensis Roem }\end{array}$ & $\begin{array}{l}\text { Inhibit the cellular entry of } \\
\text { SARS-CoV }\end{array}$ & [43] \\
\hline $\begin{array}{l}\text { Emodin derived from } \\
\text { genus Rheum and Polygo- } \\
\text { num }\end{array}$ & $\begin{array}{l}\text { Inhibit interaction of SARS- } \\
\text { CoV Spike protein and ACE } 2 \text {. } \\
\text { Inhibit the 3a ion channel of } \\
\text { coronavirus SARS-CoV and } \\
\text { HCoV-OC43 }\end{array}$ & {$[44,45]$} \\
\hline Kaempferol derivatives & $\begin{array}{c}\text { Inhibit 3a ion channel of coro- } \\
\text { navirus }\end{array}$ & {$[46]$} \\
\hline $\begin{array}{c}\text { Baicalin from Scutellaria } \\
\text { baicalensis }\end{array}$ & $\begin{array}{c}\text { Inhibit Angiotensin-converting } \\
\text { enzyme (ACE) }\end{array}$ & {$[47,48]$} \\
\hline Saikosaponins & $\begin{array}{l}\text { Prevent the early stage of } \\
\text { HCoV-22E9 infection, includ- } \\
\text { ing viral attachment and } \\
\text { Penetration }\end{array}$ & [49] \\
\hline
\end{tabular}

Table 3: Traditional Chinese Medicine for COVID-19.

\section{Conclusion}

This review provides valuable information regarding the various drugs used in Ayurveda, Unani, Homeopathy as well as in Chinese traditional medicine for the prevention and treatment of COVID-19. It focused on repurposing of drugs and possible mechanism of action in treatment of COVID-19 which may be useful for the researcher who wants to explore the hidden potential of these drugs for further research and development in the treatment of SARS CoV-2 for the treatment of COVID-19.

\section{Conflict of Interest}

None. 


\section{Bibliography}

1. MS Nadeem., et al. "Origin, potential therapeutic targets and treatment for coronavirus disease (COVID-19)”. Pathogens 9.4 (2020): 1-13.

2. I Madabhavi., et al. "CoviD-19: A review". Monaldi Archives for Chest Disease 90.2 (2020): 248-258.

3. G Duan. "Intuition on virology, epidemiology, pathogenesis, and control of COVID-19". Research in Microbiology Journal 4.5 (2020): 955-967.

4. T Singhal. "A Review of Coronavirus Disease-2019 (COVID-19)". The Indian Journal of Pediatrics 87.4 (2020): 281-286.

5. L Ang., et al. "Herbal medicine for treatment of children diagnosed with COVID-19: A review of guidelines". Complementary Therapies in Clinical Practice 39 (2020): 101174.

6. P E Gray and Y Belessis. "The use of Traditional Chinese Medicines to treat SARS-CoV-2 may cause more harm than good". Pharmacology Research 156 (2020): 104776.

7. P Sinha., et al. "Is a 'cytokine Storm' Relevant to COVID-19?". JAMA Internal Medicine 180.9 (2020): 1152-1154.

8. D E Leisman., et al. "Facing COVID-19 in the ICU: vascular dysfunction, thrombosis, and dysregulated inflammation". Intensive Care Medicne (2020).

9. T Herold., et al. "Elevated levels of IL-6 and CRP predict the need for mechanical ventilation in COVID-19". The Journal of Allergy and Clinical Immunology 146.1 (2020): 128-136.

10. A G Laing., et al. "A dynamic COVID-19 immune signature includes associations with poor prognosis". Nature Medicne 26 (2020): 1623-1635.

11. C. C. Price., et al. "Tocilizumab Treatment for Cytokine Release Syndrome in Hospitalized COVID-19 Patients". Chest (2020).

12. F Van Rhee., et al. "Siltuximab for multicentric Castleman's disease: A randomised, double-blind, placebo-controlled trial". Lancet Oncology 15.9 (2014): 966-974.

13. P La Rosée., et al. "Recommendations for the management of hemophagocytic lymphohistiocytosis in adults". Blood (2019).

14. E J Giamarellos-Bourboulis., et al. "Complex Immune Dysregulation in COVID-19 Patients with Severe Respiratory Failure". Cell Host and Microbe 27.6 (2020): 992-1000.e3.
15. A Mazzoni., et al. "Impaired immune cell cytotoxicity in severe COVID-19 is IL-6 dependent". Journal of Clinical Investigation (2020).

16. S A Baron., et al. "Teicoplanin: an alternative drug for the treatment of COVID-19?". International Journal of Antimicrobial Agents 54.4 (2020).

17. B SA., et al. "Teicoplanin: an alternative drug for the treatment of \{COVID\}-19?". International Journal of Antimicrobial Agents (2020).

18. M Costanzo., et al. "SARS-CoV-2: Recent Reports on Antiviral Therapies Based on Lopinavir/Ritonavir, Darunavir/Umifenovir, Hydroxychloroquine, Remdesivir, Favipiravir and other Drugs for the Treatment of the New Coronavirus". Current Medicinal Chemistry 27.27 (2020): 4536-4541.

19. R E Ferner and J K Aronson. "Chloroquine and hydroxychloroquine in covid-19”. BMJ 369 (2020): 9-10.

20. J Magagnoli., et al. "Outcomes of Hydroxychloroquine Usage in United States Veterans Hospitalized with COVID-19”. Med 1.1 (2020): 114-127.

21. J Chen., et al. "A pilot study of hydroxychloroquine in treatment of patients with moderate COVID-19". Zhejiang Da Xue Хие Baо. Yi Хue Ban 49.2 (2020): 215-219.

22. W Tang., et al. "Hydroxychloroquine in patients with mainly mild to moderate coronavirus disease 2019: Open label, randomised controlled trial". BMJ (2020).

23. Nct. "Hydroxychloroquine and Ivermectin for the Treatment of COVID-19 Infection".

24. E S Rosenberg., et al. "Association of Treatment with Hydroxychloroquine or Azithromycin with In-Hospital Mortality in Patients with COVID-19 in New York State". JAMA 323.24 (2020): 2493-2502.

25. "Lopinavir/ Ritonavir, Ribavirin and IFN-beta Combination for nCoV Treatment”. Case Medical Research (2020).

26. S S Jean., et al. "Treatment options for COVID-19: The reality and challenges". Journal of Microbiology, Immunology and Infection 53.3 (2020): 436-443.

27. Nct. "Efficacy and Safety of Anti HCV Drugs in the Treatment of COVID-19" (2020). 
28. R Priya and V Sujatha. "AYUSH for COVID-19: Science or Superstition?". Indian Journal of Public Health 64.4 (2020): 105-107.

29. W B Grant., et al. "Evidence that vitamin d supplementation could reduce risk of influenza and covid-19 infections and deaths". Nutrients 12.4 (2020): 988.

30. C S Kow., et al. "Vitamin d supplementation in influenza and covid-19 infections comment on: 'evidence that vitamin $d$ supplementation could reduce risk of influenza and covid-19 infections and deaths". Nutrients 12.4 (2020): 988.

31. Y Li., et al. "Traditional Chinese herbal medicine for treating novel coronavirus (COVID-19) pneumonia: Protocol for a systematic review and meta-Analysis". Systematic Reviews 9 (2020).

32. S Nikhat and M Fazil. "Overview of Covid-19; its prevention and management in the light of Unani medicine". Science of The Total Environment 728.1 (2020): 38859.

33. J Wollumbin. "Unani Tibb". Journal of the Australian Traditional-Medicine Society (2015).

34. E H Hong., et al. "Anti-influenza activity of betulinic acid from Zizyphus Jujuba on influenza A/PR/8 virus". Biomolecular Therapy 23.4 (2015): 345-349.

35. M J Oza and Y A Kulkarni. "Traditional uses, phytochemistry and pharmacology of the medicinal species of the genus Cordia (Boraginaceae)". Journal of Pharmacy and Pharmacology (2017).

36. D Kalliantas., et al. "Homeopathy combat against coronavirus disease (Covid-19)". Journal of Public Health (2020).

37. KLA To and YYY Fok. "Homeopathic Clinical Features of $18 \mathrm{~Pa}$ tients in COVID-19 Outbreaks in Hong Kong”. Homeopathy 109 (2020): 146-162.

38. D Chalia., et al. "World Homoeopathy Day 2020: Connecting digitally during the adversities of COVID-19 lockdown". Indian Journal of Research in Homeopathy 14.2 (2020): 160-167.

39. M S Refaey and M A A Fayed. "Traditional To Recent Approaches in Herbal Medicine Therapy of Covid-19". Universal Journal of Pharmaceutical Research 5.5 (2020): 71-84.

40. C W Lin., et al. "Anti-SARS coronavirus 3C-like protease effects of Isatis indigotica root and plant-derived phenolic compounds". Antiviral Research 68.1 (2005): 36-42.
41. K P Fung., et al. "Immunomodulatory activities of the herbal formula Kwan Du Bu Fei Dang in healthy subjects: A randomised, double-blind, placebo-controlled study". Hong Kong Medical Journal 17.2 (2011).

42. W Luo., et al. "Anti-SARS coronavirus 3C-like protease effects of Rheum palmatum L. extracts". Bioscience Trends 3.4 (2009): 124-126.

43. C J Chen., et al. "Toona sinensis Roem tender leaf extract inhibits SARS coronavirus replication". Journal of Ethnopharmacology 120.1 (2008): 108-111.

44. T Y Ho., et al. "Emodin blocks the SARS coronavirus spike protein and angiotensin-converting enzyme 2 interaction". Antiviral Research 74.2 (2007): 92-101.

45. S Schwarz., et al. "Emodin inhibits current through SARS-associated coronavirus 3a protein". Antiviral Research 90 (2011): 64-69.

46. S Schwarz., et al. "Kaempferol derivatives as antiviral drugs against the 3a channel protein of coronavirus". Planta Medica 80 (2014): 177-182.

47. Z Chen and T Nakamura. "Statistical evidence for the usefulness of Chinese medicine in the treatment of SARS". Phytotherapy Research 18.7 (2004): 592-594.

48. Y F Deng., et al. "Inhibitory activities of baicalin against renin and angiotensin-converting enzyme". Pharmaceutical Biology 50.4 (2011): 401-406.

49. P W Cheng., et al. "Antiviral effects of saikosaponins on human coronavirus 229E in vitro". Clinical and Experimental Pharmacology and Physiology 33.7 (2006): 612-616.

\section{Assets from publication with us}

- Prompt Acknowledgement after receiving the article

- Thorough Double blinded peer review

- Rapid Publication

- Issue of Publication Certificate

- High visibility of your Published work

Website: www.actascientific.com/

Submit Article: www.actascientific.com/submission.php Email us: editor@actascientific.com

Contact us: +919182824667 